\title{
Contrasting dynamics in activity and community composition of free-living and particle-associated bacteria in spring
}

\author{
Stefan Rösel ${ }^{1}$, Hans-Peter Grossart ${ }^{1,2, *}$ \\ ${ }^{1}$ Department of Limnology of Stratified Lakes, Leibniz-Institute of Freshwater Ecology and Inland Fisheries, Berlin, \\ Alte Fischerhütte 2, 16775 Stechlin, Germany \\ ${ }^{2}$ Potsdam University, Institute for Biochemistry and Biology, Am Neuen Palais 10, 14469 Potsdam, Germany
}

\begin{abstract}
Phytoplankton development affects the community structure and dynamics of freshwater bacteria by changing the availability of nutrients, algal exudates and biological surfaces. To elucidate these effects of phytoplankton development in spring in oligotrophic Lake Stechlin (Germany), we measured limnological and biological parameters, including the bacterial community composition (BCC), at the depth of the highest chlorophyll a concentration. To increase the resolution of BCC measurements, we separated particle-associated (PA) and free-living (FL) bacteria using serial filtration through 5.0 and $0.2 \mu \mathrm{m}$ pore size filters, respectively. The BCC of ultramicrobacteria was also determined by collecting the $0.2 \mu \mathrm{m}$ filtrate on $0.1 \mu \mathrm{m}$ filters. Changes in the community composition of Bacteria and particularly of Actinobacteria, one of the most important bacterial groups in temperate freshwater habitats, were studied via DGGE analysis of PCR-amplified 16S rRNA gene fragments. Patterns in BCC dynamics of FL Bacteria and Actinobacteria remained fairly constant throughout the study period, while patterns of PA Bacteria were more variable over time. At the breakdown of the diatom spring bloom, bacterial production and abundance sharply increased, indicating a close coupling between heterotrophic bacteria and algal detritus. The succession in BCC revealed life-style dependent patterns related to specific environmental variables. Our results indicate independent dynamics of PA and FL Bacteria as well as Actinobacteria during succession of phytoplankton spring blooms. These differences in bacterial lifestyle can only be resolved when the PA and FL fractions of microorganisms are separated.
\end{abstract}

KEY WORDS: Bacterial community composition (BCC) - Spring bloom $\cdot$ Bacteria-phytoplankton coupling $\cdot$ Pollen $\cdot$ Free-living and particle-associated bacteria $\cdot$ Lake Stechlin

\section{INTRODUCTION}

Generally, the community dynamics of aquatic bacteria vary with biotic and abiotic environmental variables, e.g. temperature, availability of nutrients, predation and interactions with other organisms, including phyto- and zooplankton (Allgaier \& Grossart 2006, Allgaier et al. 2007, Peng et al. 2007, Allgaier et al. 2008, Parveen et al. 2011). Driving forces controlling phytoplankton blooms in lakes have been intensively studied in the past, but with only little focus upon dynamics and successions of bacterial communities related to phytoplankton development in spring. Most of the previous studies have reported on the relationship between phytoplankton/primary production (PP) and the abundance/activity of bacteria (Lancelot \& Billen 1984, Simon \& Tilzer 1987). For example, Bell \& Kuparinen (1984) assessed phytoplankton and bacterioplankton production during early spring in a mesotrophic lake by following the increase in growth of diatoms and bacteria, which were stimulated by the presence of algal extracellular products. 
More recently, it has been shown that phytoplankton bloom developments have the potential to affect bacterial community composition (BCC). For example, Eiler \& Bertilsson (2004) reported that a cyanobacterial spring bloom had consequences for different groups of bacteria at the same time. In addition, other studies have investigated interactions between specific phytoplankton and heterotrophic bacteria, i.e. the occurrence of specific bacterial phylotypes associated to specific algal species. Many of these studies, however, have been performed in marine waters or in laboratory studies (e.g. Grossart et al. 2005, Rink et al. 2011, Šimek et al. 2011), whereas in freshwater ecosystems, only a few studies have investigated these interactions in situ or in field experiments with a high temporal resolution (Salcher et al. 2010, Eckert et al. 2012). Hence, there is a great need for more intensive studies of the relationship between phytoplankton blooms and shortterm changes of BCC in freshwater ecosystems, especially in spring, when environmental variables rapidly change. This gap of knowledge is surprising because bacterial activity dramatically increases during algal bloom events, when exudates and additional substrates are available (Bell \& Kuparinen 1984, Lancelot \& Billen 1984). Thereby, a substantial fraction of the PP is rapidly channelled through the microbial loop during and after such bloom events (Weisse et al. 1990) because increased concentrations of dissolved organic carbon (DOC) are released into the surrounding water either by algal exudation or microbial breakdown of the phytoplankton bloom (Bunte \& Simon 1999). Furthermore, pollen fall in spring or early summer leads to increased bacterial growth (Doskey \& Ugoagwu 1989, Graham et al. 2006, Rösel et al. 2012a), but little is known of related changes in natural BCC.

When assessing bacteria-phytoplankton interactions in the lab, Grossart et al. (2005) demonstrated that the dynamics of particle-associated (PA) and free-living (FL) bacteria communities greatly differ from each other. Hence, it is surprising that only a few studies (Selje \& Simon 2003, Allgaier \& Grossart 2006, Parveen et al. 2011, Rösel et al. 2012b) have differentiated between PA and FL bacterial fractions in natural ecosystems to better elucidate seasonal changes in BCC. Due to the high variability of nutrient availability on particles, e.g. algae exuding organic matter PA bacteria are presumably more dynamic than their FL counterparts. Moreover, our recent long-term study in mesotrophic Lake Tiefwaren (Rösel et al. 2012b) has revealed contrasting patterns in community compositions of PA and FL Bacteria and, more specifically, Actinobacteria that dominate in many temperate lakes.
Here, we hypothesize that changes in BCC are closely related to phytoplankton development in oligotrophic Lake Stechlin, particularly in spring, and both PA and FL fractions of Bacteria and dominant Actinobacteria differ in their temporal dynamics during and after the phytoplankton bloom events. The activities and community composition of the total bacterial community correlate mainly to environmental variables, e.g. temperature, $\mathrm{pH}$ and chlorophyll a (chl a), whereas those of PA Bacteria are more closely related to primary production and organic matter dynamics. This pattern greatly changes during the breakdown of the diatom spring bloom and the subsequent input of pollen grains into the lake.

\section{MATERIALS AND METHODS}

\section{Study site and sample collection}

Lake Stechlin is situated in the southern part of the Brandenburg-Mecklenburg Lake District in NE Germany (53 $10^{\prime} \mathrm{N} ; 13^{\circ} 02^{\prime} \mathrm{E}$, WGS84) and surrounded by mixed forests in all directions. It is an oligotrophic dimictic hard-water lake with a maximum depth of $69.5 \mathrm{~m}$ and a lake surface of $4.25 \mathrm{~km}^{2}$. Basic limnological and chemical variables of this well-studied lake have been previously described (Allgaier \& Grossart 2006, Rösel et al. 2012a). Lake Stechlin was sampled between the end of February and the beginning of July 2008 at least 2 or 3 times per week at the sampling site in the southern bight of the lake (max. depth $20 \mathrm{~m}$ ) in front of the Leibnitz Institute for Freshwater Ecology and Inland Fisheries, Neuglobsow. Water samples were collected at the depth of the chl a maximum, which was recorded in situ with a fluorescence probe (BackScat-I, Dr. Haardt) before sampling. Water temperature, oxygen concentration and $\mathrm{pH}$ were monitored using $1 \mathrm{~m}$ depth intervals throughout the upper $20 \mathrm{~m}$ depth.

\section{Chemical and biological variables}

Samples for dissolved organic carbon (DOC) were filtered through $0.2 \mu \mathrm{m}$ Nuclepore Track-Etch polycarbonate membranes (Whatman), which were rinsed twice with double distilled water before usage. After acidifying samples with $1 \%(\mathrm{v} / \mathrm{v})$ of $2 \mathrm{~mol} \mathrm{l}^{-1} \mathrm{HCl}$, DOC was determined as the nonpurgeable organic carbon by infrared absorption with an organic carbon analyser (multi N/C 3100, Analytic Jena AG). 
Primary production (PP) and bacterial protein production (BPP) were determined based on $\mathrm{H}^{14} \mathrm{CO}_{3}^{-}$ uptake and $\left[{ }^{14} \mathrm{C}\right]$-leucine incorporation, respectively. Subsamples of the lake water were incubated in situ for $4 \mathrm{~h}$ (PP) and $1 \mathrm{~h}$ (BPP), and measurements followed the protocols of Wetzel \& Likens (1991; PP) and Simon \& Azam (1989; BPP) with modifications after Kirchman (2001). The BPP of particle-associated (PA) and free-living (FL) microorganisms were determined after sequential filtration through 5.0 and $0.2 \mu \mathrm{m}$ cellulose-nitrate membranes, respectively (Allgaier \& Grossart 2006, Allgaier et al. 2008).

Total bacterial abundances (including PA Bacteria) in lake water samples were determined by epifluorescence microscopy after filtration of $2 \mathrm{ml}$ of lake water onto black membrane filters $(0.2 \mu \mathrm{m}$ pore size, Nuclepore Track-Etch polycarbonate membrane, Whatman). Bacterial cells were stained with 4',6diamidino-2-phenylindole (DAPI) according to Porter \& Feig (1980).

\section{Molecular analysis of 16S rRNA genes by DGGE}

\section{Filtration, DNA extraction and PCR}

For molecular analyses of bacterial community composition (BCC), PA and FL Bacteria were collected by sequential filtration of $200 \mathrm{ml}$ of lake water through filters with 5.0 and $0.2 \mu \mathrm{m}$ pore-size (47 mm diameter, Nuclepore Track-Etch polycarbonate membrane, Whatman). To also analyse the BCC of ultramicrobacteria, we further collected the $0.2 \mu \mathrm{m}$ filtrate on $0.1 \mu \mathrm{m}$ pore-size polycarbonate filters. All filters were stored frozen at $-20^{\circ} \mathrm{C}$ until DNA extraction. DNA of filtered water samples was extracted applying a standard phenolchloroform protocol (Allgaier \& Grossart 2006, Rösel et al. 2012b).

Fragments of the 16S rRNA gene were PCR-amplified for DGGE using the universal primer pair $341 \mathrm{f}$ (5'-CCT ACG GGA GGC AGC AG-3') and 907r (5'CCG TCA ATT CMT TTG AGT TT-3') (Muyzer et al. 1993) or the Actinobacteria primer pair HGC236f (5'GCG GCC TAT CAG CTT GTT-3') and HGC664r (5' AGG AAT TCC AGT CTC CCC-3') (Glöckner et al. 2000) as previously described (Rösel et al. 2012b). The universal primer pair covers $>85 \%$ of all bacteria (checked with the Ribosomal Database project [RDP] probe match tool; RDP Release 10, Update 28, http:// rdp.cme.msu.edu), and primers for Actinobacteria have a coverage rate of ca. 95\% for HGC236f and $70 \%$ for HGC664r.

\section{DGGE analysis of PCR products}

PCR products were analysed by denaturing gradient gel electrophoresis (DGGE) (Muyzer et al. 1993) using the Ingeny PhorU DGGE-System (GP Goes). DGGE runs were performed with a $7 \%(\mathrm{v} / \mathrm{v})$ polyacrylamide gel with a linear denaturing gradient of 40 to $70 \%$ urea and formamide for the universal primer pair and of 55 to $65 \%$ urea and formamide for the Actinobacteria primer pair (Rösel et al. 2012b). DGGE gels were run in $1 \times$ TAE (40 mM Tris- $\mathrm{HCl}, 20 \mathrm{mM}$ acetic acid, $1 \mathrm{mM}$ EDTA, pH 8.3) electrophoresis buffer for $20 \mathrm{~h}$ at a constant voltage $(100 \mathrm{~V})$ and a temperature of $60^{\circ} \mathrm{C}$. After electrophoresis, the DNA bands were stained with $1 \times \mathrm{SYBR}^{\circledR}$ Gold (Invitrogen).

Cluster analyses of DGGE banding patterns and statistical analyses

Cluster analyses were performed based on the similarity of the presence/absence of distinct DNA bands in different samples using the GelCompare II software package (version 5.0, Applied Maths, www. applied-maths.com). Each DGGE gel contained at least 3 lanes with a standard of 4 bands for internal and external normalisation and as an indication for quality of band separation. To avoid a distortion of the cluster analysis originating from DNA bands caused by chloroplasts, the upper part of all DGGE gels was discarded. Comparable results from previous studies and sequencing of DGGE bands indicate that amplified DNA fragments of chloroplasts are located in a specific region at the very top of the DGGE gels. In general, 5 to $10 \%$ background subtractions, depending on the signal-to-noise ratio of the gels, were applied. Banding patterns were compared on a band-by-band basis using Dice correlation as a similarity coefficient and an unpaired group method of analysis (UPGMA) to generate a dendrogram for selected lanes. Additionally, we extracted semi-quantitative data of relative band intensities from the DGGE gels and compared them with the binary presence/absence table using non-metric multidimensional scaling (NMS) analyses. This well established multivariate method for the representation of community structure has great flexibility in accommodating biologically relevant relationships (Clarke 1993, Clarke \& Ainsworth 1993). NMS is an ordination method that applies an iterative optimisation procedure to plot samples in 2 dimensions, whereby distances between the points indicate the degree of similarity among DGGE banding patterns. 
In comparison to other multivariate statistical methods, NMS ordinations have the advantage of avoiding distortions originating from the non-normal distribution of phylotype data obtained from DGGE profiles and environmental data. NMS analyses were conducted with 99 runs and according to the BrayCurtis dissimilarity algorithm. Analyses with quantitative data based on standardised band intensities of DGGE gels yielded similar results in NMS compared to presence/absence data of DGGE banding patterns, but with a higher resolution. Therefore, we subsequently calculated all statistical analyses with relative and standardised band intensities. Similarity matrices for NMS analyses were generated using the Bray-Curtis algorithm. To calculate NMS for limnological variables, the environmental data were normalised, and calculations were done with the Euclidean distance algorithm for resemblance (Clarke 1993). Clusters among the samples in this analysis as well as in the NMS of BCC were classified according to limnological and biological measurements.

We compared DGGE profiles with the respective physicochemical variables by performing several Mantel tests (Mantel 1967) with 999 randomised runs using Spearman's rank correlation method for each parameter. As a proxy for chemical and biological variables interacting with $\mathrm{BCC}$, we chose the temperature of the sampling depth, $\mathrm{pH}, \mathrm{DOC}, \mathrm{chl} a$, total PP and BPP. The Mantel test is an extremely versatile statistical test for comparison of distances between environmental data and species or bacterial abundance. Due to multiple comparison and non-independence issues and according to Bonferroni corrections for multiple comparisons on non-independent similarity matrices, the significance level of our Mantel tests is $\leq 0.008$ (6 tests). To identify specific environmental variables affecting changes in $\mathrm{BCC}$, detrended correspondence analysis (DCA) was conducted after log-transformation of chl a data and DOC concentrations to fulfil the assumptions of normal distribution. For PP and activity of heterotrophic bacterioplankton, we analysed the incorporation rates of total PP and BPP (PA plus FL communities) as a proxy for phytoplankton and bacteria, respectively. DCA has some advantages over reciprocal averaging and multidimensional scaling, and corrects the faults (e.g. arch effects) caused by correspondence analysis (Hill \& Gauch 1980, Peet et al. 1988). Detrending was calculated with 26 segments (the default settings of the software PAST) as recommended by Jackson \& Somers (1991).

Statistical analyses were conducted using the statistical package OriginPro 8 (version 8.5, OriginLab Corporation, www.originlab.com), Primer 6 (version 6.1. 12, PRIMER-E, www.primer-e.com) and the software PAST (version 2.14, http://folk.uio.no/ohammer/past).

\section{RESULTS}

\section{Environmental and biological variables}

Depth profiles of chl a concentrations (Fig. 1) revealed a pronounced spatiotemporal pattern in phytoplankton development: (1) A phytoplankton spring bloom mainly consisting of diatoms Bacillariophyceae occurred in the second half of March, which was initiated in a water depth of 4 to $5 \mathrm{~m}$ (chl a > $8 \mu \mathrm{g} \mathrm{l}^{-1}$ ) but quickly dispersed into the whole water column, reaching a depth of up to $18 \mathrm{~m}$. (2) Thereafter, chl a rapidly decreased from $>8 \mu \mathrm{g} \mathrm{l}^{-1}$ to $<3 \mu \mathrm{g} \mathrm{l}^{-1}$ in late March and early April. (3) In mid April, a second but less pronounced maximum of chl a occurred below the thermocline, which consisted of an almost equal mixture of Bacillariophyceae, Cryptophyceae and Chrysophyceae and lasted until May in the deeper water layer (below $10 \mathrm{~m}$ ). (4) Meanwhile, chl a concentrations dropped in the epilimnion and later in the whole

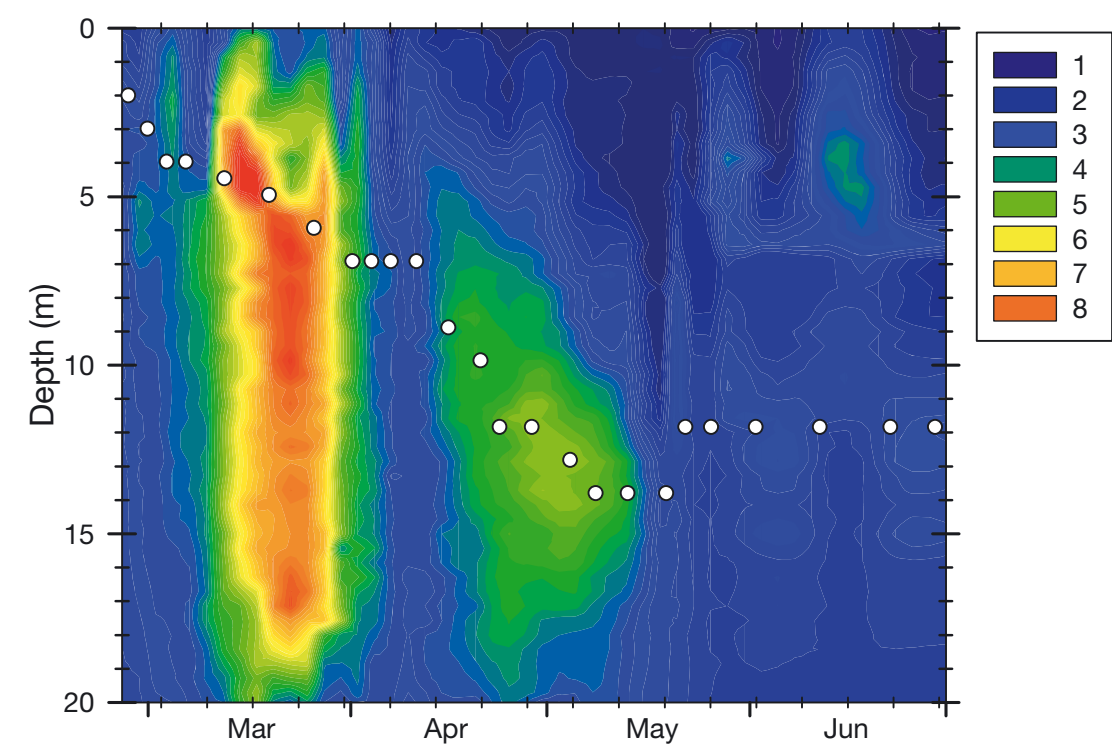

Fig. 1. Concentrations of chl $a$ in Lake Stechlin measured by a fluorescence probe. Chl a values are colour-coded $\left(\mu \mathrm{g} \mathrm{l}^{-1}\right)$. O: sampling depth 
water column, indicating a 'clear water phase' until mid-June, when a small chl a maximum developed at 3 to $5 \mathrm{~m}$ depth. (5) $\mathrm{Chl}$ a concentrations remained rather low in summer, but (6) strongly increased in late summer (August and September) when a cyanobacterial bloom evolved (data not shown). The white dots in Fig. 1 represent the depth of sampling, which was $2 \mathrm{~m}$ at the start and $12 \mathrm{~m}$ at the end of our sampling campaign (see Table S1 in the supplement at www.int-res.com/articles/suppl/a066p169_ supp.pdf). Samples were preferentially taken at the depth of the chl a maximum, and the water temperature varied little between 4 and $7^{\circ} \mathrm{C}$. In contrast, the water temperature at the surface rapidly increased in spring and reached up to $20^{\circ} \mathrm{C}$ in summer. To minimise the effect of increasing water temperature, in the second half of the present study, water samples were collected at a depth of $\geq 12 \mathrm{~m}$, neglecting the small and local chl a maxima in the epilimnion.
Table S1 provides an overview of selected sampling data (dates, sampling depth, surface water temperature and that of the water sample, $\mathrm{pH}$, DOC concentrations and lake status). In Lake Stechlin, $\mathrm{pH}$ values ranged between 7.8 and 8.8 , and DOC concentrations peaked twice, (1) once during the diatom spring bloom and its breakdown $\left(62 \mathrm{mg} \mathrm{l}^{-1}\right)$ and (2) when pine pollen was massively introduced from the surrounding forests into the lake in June $\left(33 \mathrm{mg} \mathrm{l}^{-1}\right)$. Grains of pine pollen were visibly floating on the water surface but were also dispersed throughout the whole water column and were microscopically detectable in all water samples at that time.

During the whole study period, patterns of PP paralleled those of chl $a$, with a clear increase at the beginning of the phytoplankton spring bloom in March (Fig. 2A) leading to a highly significant correlation between chl $a$ and PP (regression analysis, $\mathrm{R}=0.818, \mathrm{p}<$ $0.001, \mathrm{n}=16$ ). BPP slightly increased (mainly of FL Bacteria) throughout the bloom, but strongly increased
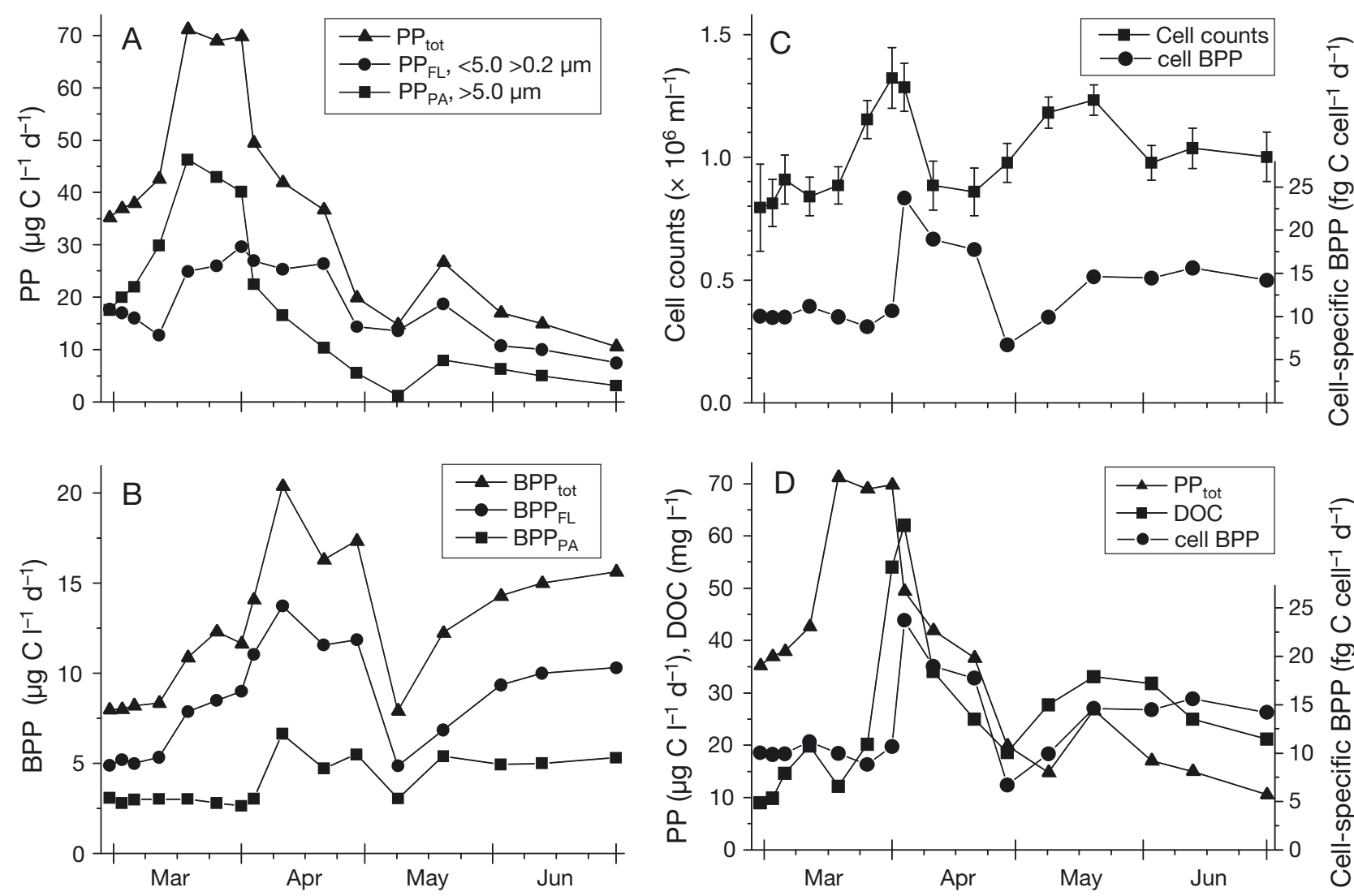

7
$\frac{1}{0}$
$\frac{1}{0}$
0
0
0
0
0
0
0
0
0
00
0
0
1
$\frac{1}{0}$
0

Fig. 2. Biological variables measured in Lake Stechlin during and after the phytoplankton spring bloom of 2008. (A) Primary production (PP) of large phytoplankton or algal aggregates $\left(>5.0 \mu \mathrm{m}, \mathrm{PP}_{\mathrm{PA}}\right)$ and small phytoplankton $\left(<5.0 \mathrm{but}>0.2 \mu \mathrm{m}, \mathrm{PP} \mathrm{FL}_{\mathrm{FL}}\right)$ and total PP $\left(\mathrm{PP}_{\text {tot }}\right)$. (B) Bacterial protein production (BPP) of PA $\left(\mathrm{BPP}_{\mathrm{PA}}\right)$ and FL $\left(\mathrm{BPP}_{\mathrm{FL}}\right)$ fractions and total $\left(\mathrm{BPP}_{\text {tot }}\right)$ measured by $\left[{ }^{14} \mathrm{C}\right]$-leucine incorporation ( $\mu \mathrm{g} \mathrm{C}^{-1} \mathrm{~d}^{-1}$ ). PA: particle-attached; FL: free-living. (C) Total bacterial abundances determined microscopically after DAPI staining of bacterial cells (cell counts $\times 10^{6} \mathrm{ml}^{-1}$ ) and cell-specific BPP (fg C cell ${ }^{-1} \mathrm{~d}^{-1}$ ). (D) Comparison of $\mathrm{PP}_{\text {tot }}, \mathrm{DOC}$ and cell-specific BPP 
during the breakdown of the phytoplankton bloom, which was related to both bacterial size-fractions (PA and FL; Fig. 2B). After a short decline, BPP increased in parallel to pollen input, whereas $\mathrm{PP}$ and chl a were low. Bacterial cell numbers (Fig. 2C) reached maximum values of $1.32 \times 10^{6} \pm 0.12 \times 10^{6}$ cells ml $^{-1}(\mathrm{n}=$ 16), and were significantly higher during the phytoplankton bloom and its breakdown (2-sample $t$-test, $\mathrm{p}<0.05$, df $=10$ ). Based on total BPP and bacterial abundance, cell-specific bacterial activities could be calculated (Fig. 2C,D). Bacterial carbon incorporation was initially ca. $10 \mathrm{fg} \mathrm{C}$ cell ${ }^{-1} \mathrm{~d}^{-1}$ but increased by ca. 2.5-fold during the degradation of the phytoplankton bloom, when DOC concentrations were high. Dynamics of bacterial activity can be directly linked to DOC concentrations, which also increased during the input of pollen into the lake from June to July (Fig. 2D). This suggests that the senescent phytoplankton and pollen input provide an excellent nutrient and organic matter source for bacterial growth. Pollen grains serve as an important nutrient and organic matter source for pelagic bacteria, especially when phytoplanktonderived substrates are low during the clear water phase.

The DCA (Fig. 3) and an NMS plot of the measured physical, chemical and biological variables (data not shown) indicate a clear succession of the lake status. Statistical ordination analyses revealed a distinct seasonal clustering and a clear classification of samples according to the lakes' status. At the beginning of our measurements, the lake was not stratified, and

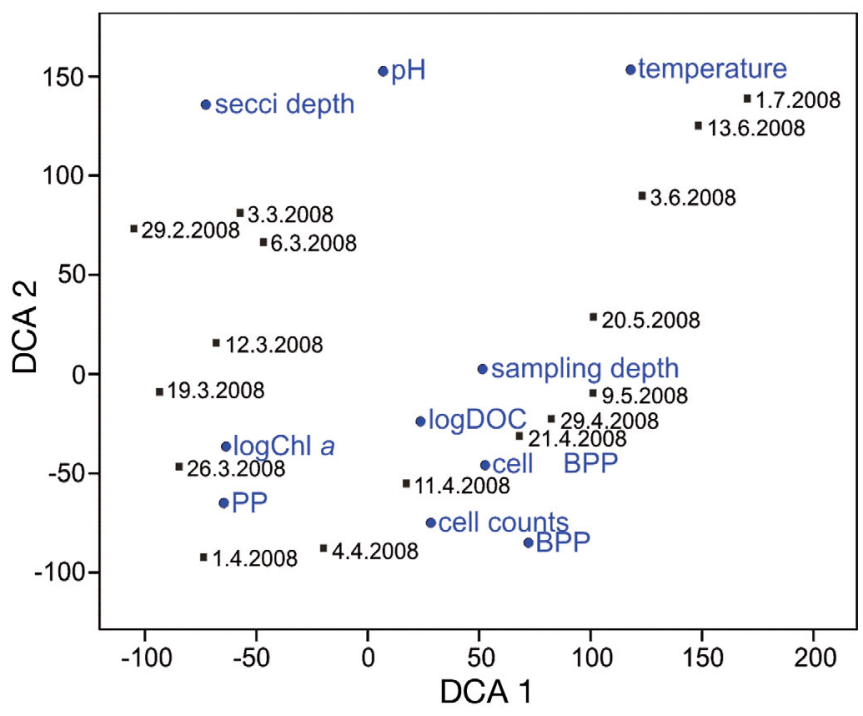

Fig. 3. Detrended correspondence analysis (DCA) for environmental variables of Lake Stechlin during and after the phytoplankton spring bloom in 2008. Data of physicochemical and biological parameters were normalised, and detrending was calculated with 26 segments. •: environmental variables, $\mathbf{~}:$ sampling dates water temperature was ca. $4{ }^{\circ} \mathrm{C}$, but in early March, chl $a$ and PP strongly increased due to the onset of the diatom spring bloom. Thereafter, another cluster emerged when pollen input led to increased DOC concentrations and, hence, high BPP in Lake Stechlin. DCA was applied to assess the major environmental variables and driving forces affecting BCC. Temperature and $\mathrm{pH}$ as well as other biological variables, such as PP, chl a and BPP, may partly explain the variability in bacterioplankton development. Dynamics of heterotrophic activity directly parallel DOC concentrations and bacterial abundance; PP and BPP seem to be (partly) independent, as indicated by 2 different ordinations.

\section{Bacterial community composition of PA and FL Bacteria}

Cluster analyses of BCC for PA and FL Bacteria (Fig. 4A) demonstrate that DGGE banding patterns for both fractions are distinct and result in the formation of 2 separate clusters, as indicated by the UPGMA dendrogram. Several DNA bands (ca. 15 to 20) were detected in each sample. A Mantel test for comparison between the PA and FL DGGE banding patterns confirmed that the fractions are not similar $(p>0.474)$. Temporal dynamics were more pronounced for PA than for FL Bacteria (Fig. 4A,B), and FL Bacteria seemed to be relatively stable throughout the sampling period. This is indicated by a higher similarity in DGGE banding patterns of FL than of PA bacterial communities (Fig. 4A). Cluster similarity between PA and FL bacteria was $62 \%$ but reached $72 \%$ within the PA cluster and even $90 \%$ within the FL cluster. This pattern was supported by NMS analysis (Fig. 4B) yielding a narrow cluster of FL Bacteria and a much wider cluster of PA Bacteria (stressvalue of NMS ordination is $\leq 0.06$ ).

A progressing development in BCC of both bacterial fractions (Fig. 5A,B) results in distinct clusters of PA and FL Bacteria over time reflecting the respective environmental state of the lake: (1) absence of stratification, (2) phytoplankton spring bloom with increased PP and chl $a$, (3) deep chl a maximum with high BPP and (4) input of pollen in June and July with high DOC. This classification is valid for both the PA and FL bacterial fractions, but it is more apparent in the PA fraction.

In addition to the PA and FL bacterial fractions, we analysed ultramicrobacteria (cell sizes of $>0.1 \mu \mathrm{m}$ and $<0.2 \mu \mathrm{m}$; see Fig. S1A in the supplement at www.int-res.com/articles/suppl/a066p169_supp.pdf). 
Although several DGGE bands (ca. 20) occurred in this fraction, only a few DGGE bands were exclusively found there. Most bands were affiliated to both size fractions (FL and ultramicrobacteria), but several bacteria did not pass through the $0.2 \mu \mathrm{m}$ filter, and hence, no bands were detectable in the ultramicro- bacterial fraction. The composition of ultramicrobacteria is more variable than that of the FL fraction, as indicated in the NMS plot (see Fig. S1B in the supplement). FL Bacteria showed a distinct and narrow cluster, whereas ultramicrobacteria formed a more versatile and broader cluster.
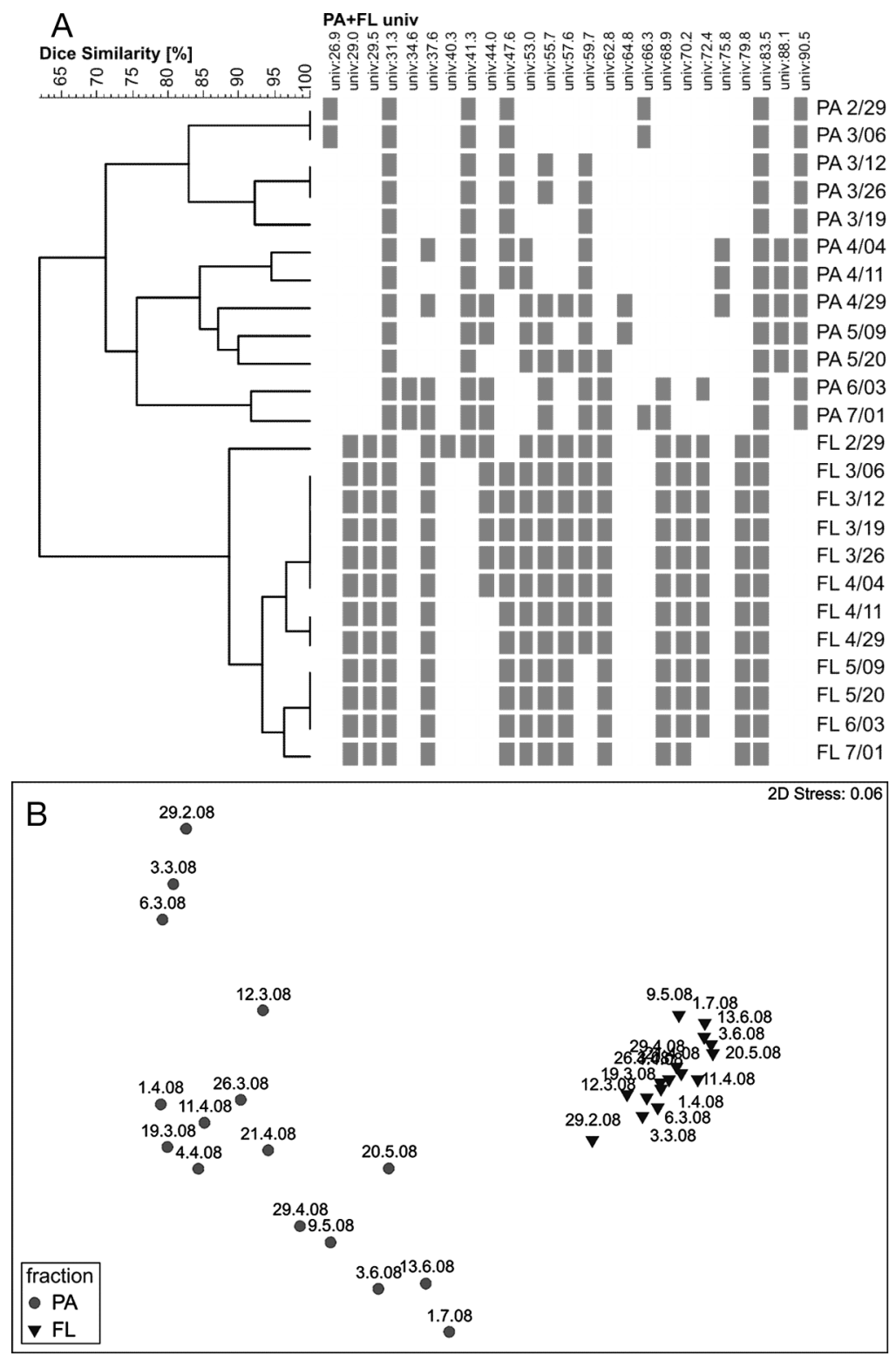

Fig. 4. (A) Cluster analysis of DGGE banding patterns of particle-attached $\left(\mathrm{PA}_{i}>5.0 \mu \mathrm{m}\right)$ and free-living $\left(\mathrm{FL}_{i}<5.0\right.$ but $\left.>0.2 \mu \mathrm{m}\right)$ Bacteria in Lake Stechlin from March to July. Dice similarity within the PA fraction is $72 \%$; within FL it is $90 \%$ and between PA and FL $62 \%$. Sampling dates are given as month/day; univ: universal primer. (B) Nonmetric multidimensional scaling $(\mathrm{NMS})$ plot representing differences between PA $(\bullet)$ and FL $(\boldsymbol{\nabla})$ bacterial communities. Bray-Curtis similarities (Dice correlation) were calculated from DGGE banding patterns of DNA samples from Lake Stechlin during and after the phytoplankton spring bloom. Samples are standardised by total; resemblance was done according to the Bray-Curtis similarity algorithm

\section{Bacterial community composition of PA and FL Actinobacteria}

Actinobacteria are one of the most abundant and common bacterial groups in temperate freshwater ecosystems. Their relatively high phylogenetic diversity was indicated by 15 to 20 DNA bands per sample and size fraction. DGGE banding patterns of FL and PA Actinobacteria showed distinct differences in their dynamics, which is indicated by the formation of fraction specific clusters in the DGGE profile (Fig. 6). In parallel to PA Bacteria, the seasonal dynamics of PA Actinobacteria were more pronounced than that of FL Actinobacteria. Some dominant bands exclusively occurred either in the PA or FL fraction, but the majority of FL actinobacterial DGGE bands also appeared in the PA fraction. Similar to Bacteria, the clustering similarity between PA and FL Actinobacteria was lower $(68 \%)$ than that within the PA $(72 \%)$ or FL $(90 \%)$ actinobacterial fractions. Within the FL Actinobacteria, some samples even showed analogous DGGE banding patterns and, therefore, can be assumed to be identical (e.g. in March and April). The spatiotemporal succession of Actinobacteria was similar in both fractions (PA and FL) and can be related to lake status in parallel to those of $B a C$ teria (Fig. 5C,D). In both actinobacterial fractions, some analogous patterns developed and are well related to limnological data.

\section{Relationship between community composition and environmental variables}

Cluster analyses and statistical correlations (Mantel tests) demonstrate 

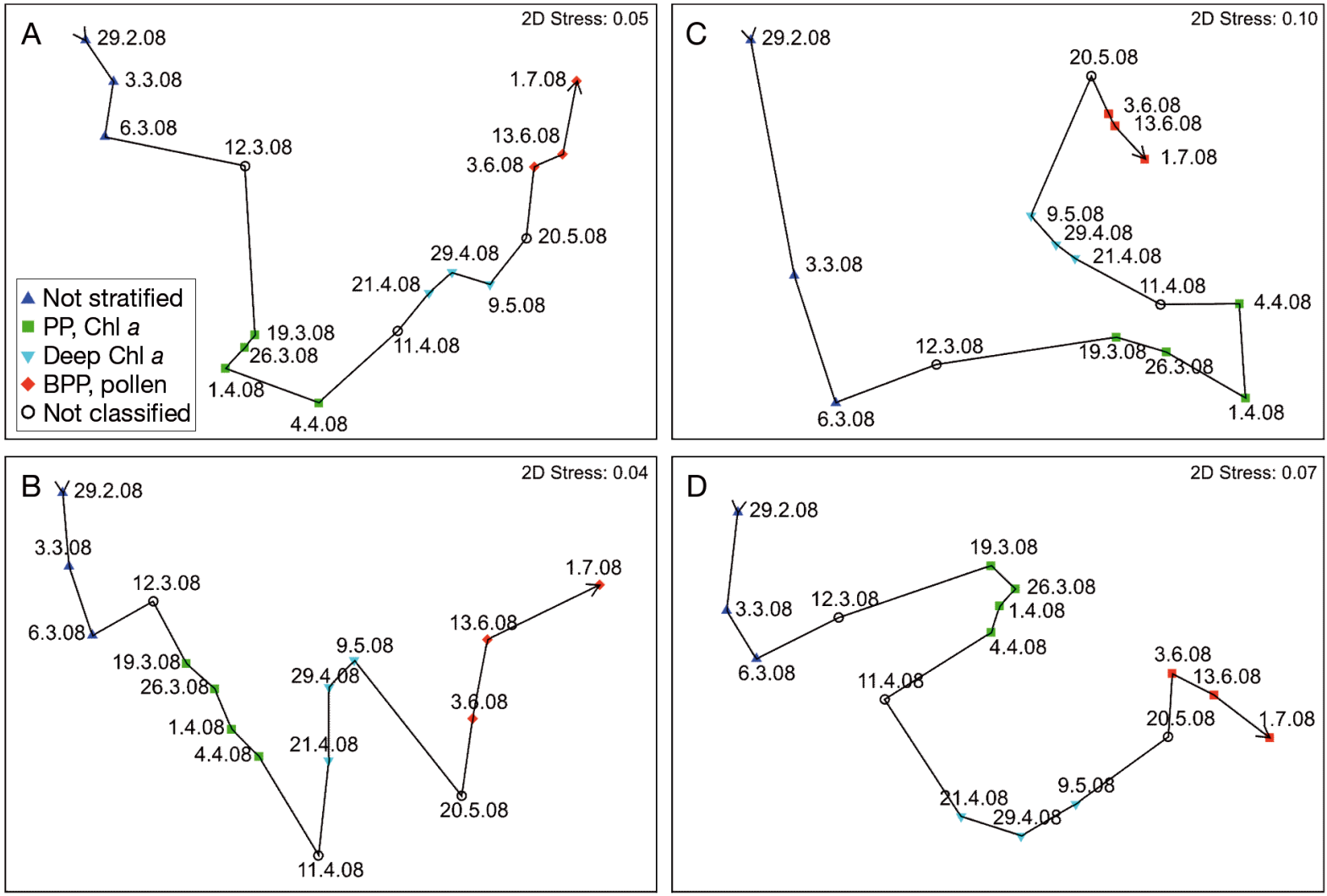

Fig. 5. NMS plot for DGGE banding patterns of bacterial communities calculated using Dice correlation (Bray-Curtis similarity). Consecutive sampling dates have been connected to illustrate the time series. Colour-coded symbols are based on classifications of the limnological characteristics of the lake status (destratified, high PP and chl a, maximum of deep chl a or high BPP), Stress values are $\leq 0.1$. (A) Particle-attached $\left(\mathrm{PA}_{;}>5.0 \mu \mathrm{m}\right)$ and $(\mathrm{B})$ free-living $\left(\mathrm{FL}_{;}<5.0\right.$ but $\left.>0.2 \mu \mathrm{m}\right)$ Bacteria; (C) PA and (D) FL Actinobacteria. Samples were standardised by total; resemblance was done according to the Bray-Curtis similarity algorithm

that although water temperature stayed rather constant at the depth of sampling, it is a major driver for the observed dynamics in BCC $(\mathrm{p}<0.001)$. A summary of all statistical results based on the separation between PA and FL Bacteria and Actinobacteria is given in Table 1. Our Mantel tests and DCA analysis show a strong correlation between the $\mathrm{BCC}$ of PA Bacteria and PP and between the BCC of both PA and FL Bacteria or Actinobacteria and temperature as well as $\mathrm{pH}(\mathrm{p}<$ 0.001). Surprisingly, the BCC of neither the bacterial nor actinobacterial fractions was significantly correlated to chl $a$, Secchi depth or DOC concentrations $(\mathrm{p}>0.05)$.

Table 1. Statistical comparison of DGGE banding patterns and selected environmental variables. Results of Mantel tests for particle-attached (PA) and free-living (FL) Bacteria and Actinobacteria. Values in bold indicate highly significant ( $\mathrm{p}<0.01$ ) correlations, according to multiple comparisons on non-independent similarity matrices and Bonferroni corrections; significance level $\leq 0.008$ ( 6 tests)

\begin{tabular}{|c|c|c|c|c|c|c|c|c|}
\hline & \multicolumn{2}{|c|}{ PA Bacteria } & \multicolumn{2}{|c|}{ FL Bacteria } & \multicolumn{2}{|c|}{ PA Actinobacteria } & \multicolumn{2}{|c|}{ FL Actinobacteria } \\
\hline & $\rho$ & Significance & $\rho$ & Significance & $\rho$ & Significance & $\rho$ & Significance \\
\hline & $\%$ & $\mathrm{p}$ & $\%$ & $\mathrm{p}$ & $\%$ & $\mathrm{p}$ & $\%$ & $\mathrm{p}$ \\
\hline Temperature $\left({ }^{\circ} \mathrm{C}\right)$ & 68.0 & 0.001 & 57.6 & 0.001 & 36.9 & 0.001 & 55.2 & 0.001 \\
\hline 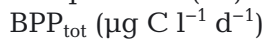 & 28.8 & 0.008 & 39.9 & 0.001 & 28.5 & 0.008 & 32.4 & 0.003 \\
\hline $\mathrm{PP}_{\text {tot }}\left(\mu \mathrm{g} \mathrm{C \textrm {l } ^ { - 1 } \mathrm { d } ^ { - 1 } )}\right.$ & 32.4 & 0.006 & 16.2 & 0.067 & 19.5 & 0.034 & 29.2 & 0.011 \\
\hline Chl a $\left(\mu g l^{-1}\right)$ & 10.2 & 0.411 & 3.9 & 0.527 & 11.2 & 0.389 & 3.7 & 0.563 \\
\hline $\operatorname{DOC}\left(\mathrm{mg} \mathrm{l}^{-1}\right)$ & 20.8 & 0.024 & 13.3 & 0.173 & 40.8 & 0.011 & 14.2 & 0.133 \\
\hline $\mathrm{pH}$ & 75.3 & 0.001 & 67.6 & 0.001 & 79.5 & 0.001 & 65.7 & 0.001 \\
\hline
\end{tabular}




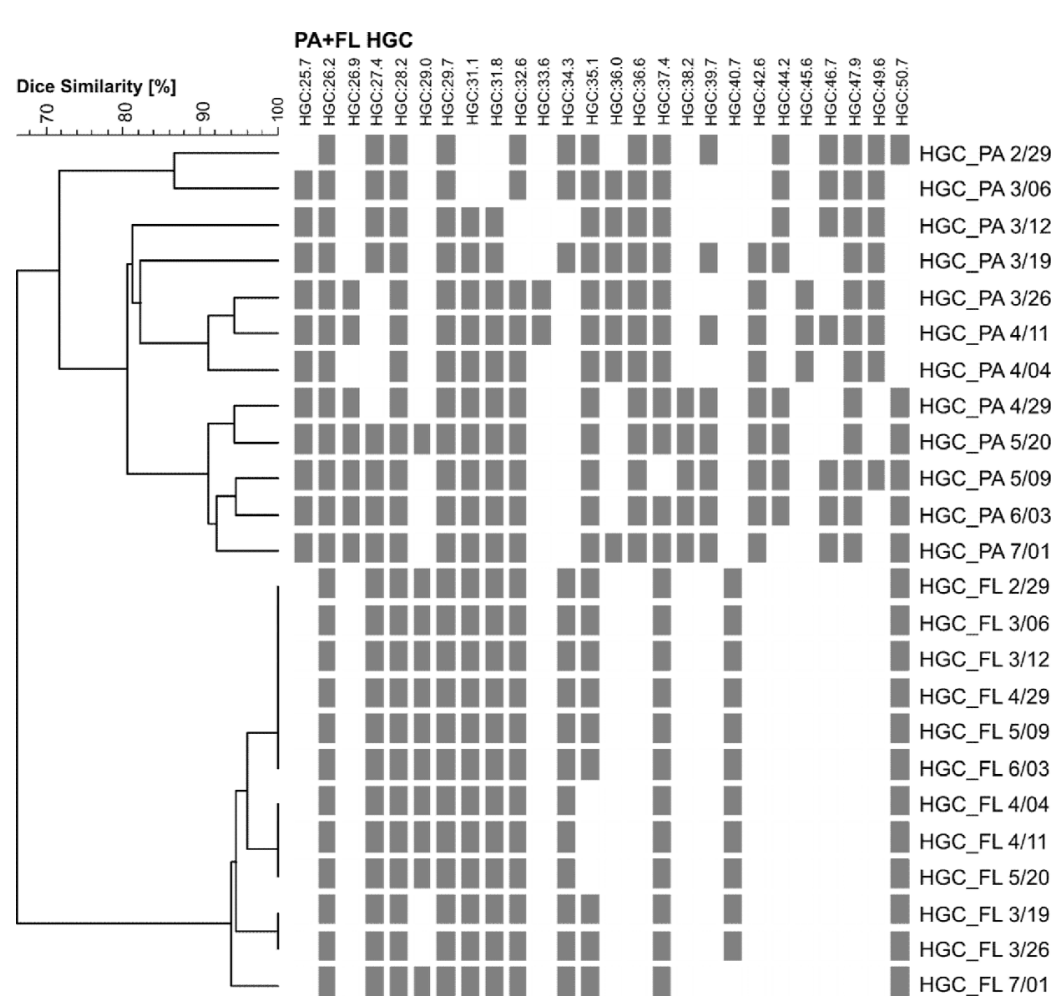

Fig. 6. Actinobacteria. Cluster analysis and UPGMA dendrogram calculated from the respective DGGE banding patterns of particle-attached (PA; $>5.0 \mu \mathrm{m})$ and free-living $\left(\mathrm{FL}_{i}<5.0\right.$ but $\left.>0.2 \mu \mathrm{m}\right)$ fractions of Actinobacteria using Dice correlation. HGC: high content on $\mathrm{G}+\mathrm{C}$

\section{DISCUSSION}

\section{Bacterial activities in relation to phytoplankton spring development}

Dynamics in BCC are mainly based on changes in bacterial activities, which are directly related to changes in environmental conditions. These changes are greatest during the phytoplankton spring bloom development. However, the dominance of major bacterial groups is not exclusively coupled to the activity of the same phylotype (Pérez \& Sommaruga 2011). In Lake Stechlin, the development of the diatom spring bloom resulted in a parallel increase of PP and bacterial cell counts, whereas BPP followed this trend with a delay of several days. Thus, the abundance of bacteria was highest at the end of the phytoplankton spring bloom, and BPP strongly increased during the phytoplankton bloom breakdown, with the highest cell-specific BPP rates at that time. Nevertheless, there may be seasonal variations in bacterial activities that depend on both phytoplankton and bacterial community dynamics. For example, the breakdown of algal bloom events often results in a massive accumulation of DOC in the surrounding water. DOC uptake and utilisation by bacteria as a substrate and energy source has been demonstrated earlier (Bunte \& Simon 1999, Weiss \& Simon 1999), but DOC utilisation rates can greatly vary with DOC quality and quantity and with $\mathrm{BCC}$. These findings suggest that specific bacterial communities have different preferences for bacterial substrates depending on their metabolic capabilities.

Hence, phytoplankton bloom dynamics have the potential to considerably affect bacterial activities and community structure. For example, cyanobacterial spring blooms in Swedish freshwater ecosystems affected several phylogenetic groups of bacteria at the same time (Eiler \& Bertilsson 2004, Eiler et al. 2006), whereby a consistent trend in the relationship of filamentous cyanobacteria to specific bacterial lineages became evident. In Lake Zürich, the filamentous cyanobacterium Planktothrix rubescence is usually the dominant primary producer, but it does not provide an appropriate carbon source for heterotrophic bacteria and, thus, seems to compete with other autotrophic and heterotrophic prokaryotes (Van den Wyngaert et al. 2011). Uncoupling of heterotrophic bacteria from phytoplankton growth also occurs when phosphorus limits bacterial growth, but nitrogen limits that of phytoplankton (Vrede et al. 1999). Although the authors suggest that an uncoupling of BPP from PP is a common phenomenon in lakes, a close coupling between autotrophic algae and heterotrophic bacteria has been found. Therefore, algal exudates serve as an important bacterial energy and organic matter source (Bell \& Kuparinen 1984, Lancelot \& Billen 1984, Simon \& Tilzer 1987, Coveney \& Wetzel 1995).

In the present survey, phytoplankton development and bacterial dynamics were closely linked to each other, but this coupling greatly depends on bacterial lifestyle. Whereas BPP of FL Bacteria increased in parallel to phytoplankton growth during the diatom bloom, BPP and cell number of PA Bacteria rapidly increased during the breakdown of the algal bloom, indicating increased bacterial colonisation and subsequent algal cell lysis. However, the subsequently increased concentrations of DOC in the surrounding water also stimulated the growth of FL Bacteria. These findings indicate that the activities of FL Bac- 
teria are directly related to DOC released by either algal exudation or lysis of algal cells. In contrast, PA Bacteria seem to actively exploit the algal cells upon attachment to the algal surface. This is also in agreement with findings by Grossart et al. (2007), which indicate that many aquatic bacteria are able to upregulate their enzymatic activities immediately upon attachment to biological surfaces.

\section{Separation into PA and FL bacterial fractions improves the resolution of $\mathrm{BCC}$ dynamics}

Generally, aquatic bacterial communities are analysed by filtration onto $0.2 \mu \mathrm{m}$ pore size membrane filters after a prefiltration step through large filter pore sizes or gauzes to remove large eukaryotic organisms. However, to better distinguish among different bacterial life styles, e.g. bacteria that are attached to organic particles and organisms, some authors (Selje \& Simon 2003, Grossart et al. 2005, Allgaier \& Grossart 2006, Allgaier et al. 2007, Parveen et al. 2011, Rink et al. 2011) have separated the bacterial community into 2 size fractions to differentiate between the free-living (FL) and particle-associated (PA) bacterial life stages. This operational separation is a first step to account for different life stages of pelagic bacteria, which generally fall into 3 categories: (1) truly free-living bacteria, (2) microorganisms that attach to particles and organisms and (3) those alternating between both FL and PA life stages (Grossart 2010, Grossart \& Tang 2010). The concept of different bacterial 'lifestyles' is also supported by functional predictions from sequenced whole bacterial genomes, which indicate that the group of small $(<5.0 \mu \mathrm{m})$ FL Bacteria contains a few taxa that are nearly always abundant, whereas another fraction, presumably consisting of PA Bacteria, is highly dynamic and more infrequently present (Yooseph et al. 2010). However, many pelagic bacteria can potentially switch between these different life strategies depending on environmental conditions, such as the availability of inorganic nutrients and dissolved or particulate organic substrates. Nevertheless, because both fractions seem to be significantly different, the separation into FL and PA Bacteria achieves a much better correlation between changes in BCC and given environmental variables (e.g. Allgaier \& Grossart 2006, Rösel et al. 2012b).

The second maximum in bacterial activities in the present study was not related to phytoplankton but to increased nutrient and DOC concentrations following a massive input of pine pollen into Lake Stechlin in June (Rösel et al. 2012a). These distinct changes in lake chemistry also have a strong effect on the BCC of both PA and FL fractions.

Hence, it is surprising that, to date, only a handful of aquatic microbial ecologists have differentiated between FL and PA bacteria. In most studies separating between these bacterial fractions, distinct differences in BCC between both size fractions were evident (Allgaier \& Grossart 2006, Allgaier et al. 2007, Parveen et al. 2011, Rösel et al. 2012b). In the present study, the dynamics in BCC of PA Bacteria were highly variable and closely related to phytoplankton development in spring, whereas FL bacteria remained more similar over time. The higher temporal stability of FL BCC is indicated by narrow clusters obtained either by cluster analysis of DGGE banding patterns or by NMS analysis. Thereby, the 2 groups that we analysed, i.e. Bacteria and Actinobacteria, showed comparable patterns in both fractions.

The greater dynamics of ultramicrobacteria $(<0.2 \mu \mathrm{m})$ suggest that the separation of this size fraction is operational and not related to 'true' differences in bacterial lifestyle. This size fraction of small bacteria is neglected in most of the previous studies, but its high diversity with sometimes a few unique DGGE bands indicates that a part of the whole bacterial diversity could be missed when excluding this size fraction. This difference could be even more pronounced in ultra-oligotrophic environments and when rare phylotypes, which are supposed to be 'dormant', are addressed using next generation sequencing. Dormancy is a commonly used strategy by a variety of microorganisms to overcome unfavourable environmental conditions. The proportion of dormant and small bacteria can reach up to $40 \%$ of taxon richness in nutrient-poor as well as productive aquatic ecosystems (Jones \& Lennon 2010).

\section{Changes in BCC are closely related to specific environmental changes}

In the present study, we used the well-established DGGE approach (Muyzer et al. 1993) because we wanted to analyse the dominant and most active bacterioplankton community in relation to changes in phytoplankton development and environmental variables in spring. DGGE is a powerful and easy tool for monitoring BCC, especially to track changes in BCC related to environmental conditions (Muyzer \& Smalla 1998).

The lake status in spring seems to follow a predetermined path, changing from a mixed and un- 
stratified water column to a well-stratified stage thereafter. In parallel, the diatom spring bloom was replaced by a second phytoplankton bloom, which exclusively occurred below the thermocline when the lake became stratified. This smaller bloom was terminated by the clear water phase caused by grazing of micro- and metazooplankton. At the same time, a massive input of pine pollen into the lake fertilised bacterial processes and enhanced BPP and bacterial abundances. Interestingly, these changes are reflected in the succession of the BCC in both bacterial fractions, which is well supported by our NMS analyses. Thereby, clustering of PA Bacteria and Actinobacteria is much more pronounced than that of FL Bacteria and Actinobacteria. In parallel to other diatom bloom studies, the bacterial colonisation of algal cells during the post-bloom phase was accompanied by major changes in BCC, particularly of PA Bacteria. These evident changes in BCC were concomitant with increases in the abundance and growth rate of both PA and FL Bacteria, but bacteria attached to particles seemed to be more affected by the diatom bloom than their free-living counterparts.

Other studies analysing seasonal patterns in bacterioplankton succession via the DGGE approach revealed a temporal development of $\mathrm{BCC}$ resulting in distinct bacterial clusters during and after the phytoplankton spring bloom, similar to those of the present study (Zwisler et al. 2003, Peng et al. 2007, Rösel et al. 2012b). Many studies show that phytoplankton dynamics have a significant impact on BCC (e.g. Cole 1982, Lindström 2001, Eiler \& Bertilsson 2004, Peng et al. 2007). Although phytoplankton and bacterial dynamics are closely linked with each other, little is known of how these communities interact with each other at the species level. Hence, in vitro studies have been conducted to examine the BCC and spatiotemporal succession of bacteria in the presence of different phytoplankton substrates. Šimek et al. (2011) showed that different bacterial lineages are related to specific algal cultures excreting various extracellular products. Depending on different environmental conditions, algal-derived organic matter may select for specific bacteria by increasing their growth. Indeed, some bacterial strains respond well and rapidly adapt to specific algae, leading to niche separation, e.g. Limnohabitans strains (Betaproteobacteria; Šimek et al. 2011). In our study, we could not measure the algal exudation of specific substances, and hence, underlying mechanisms of the coupling between distinct bacterial phylotypes and specific algae cannot be resolved.

Unfortunately, we could not account for changes in $\mathrm{BCC}$ and bacterial growth caused by grazing of het- erotrophic nanoflagellates and ciliates, which are known to greatly affect total bacterial activities and BCC at the same time (Šimek et al. 2002, 2008). Because pronounced spatiotemporal changes of FL actinobacterial communities were absent, it is very likely that this bacterial group, consisting of predominantly small cells, is well protected against protozoan grazing (Salcher et al. 2010).

A high spatial and temporal resolution is necessary to assess the relationship between specific bacterial phylotypes and various highly variable environmental parameters. Yannarell et al. (2003) analysed time series of ARISA profiles from various lakes and retrieved a general pattern of seasonally changing BCC. Bacterial community structure appeared to be stable in spring, but seasonal changes in environmental parameters acted as important structuring forces of BCC in different lakes. These driving seasonal forces were important for the consecution of BCC in each studied lake (Yannarell et al. 2003). When mapping DGGE banding patterns with NMS plots and performing statistical analyses, we found distinct clusters related to high PP and chl a concentrations, but the BCC of neither PA nor FL Bacteria was significantly correlated to chl a. Furthermore, DCA and Mantel tests that compared the similarity between $\mathrm{BCC}$ and environmental variables showed a strong linkage between the $\mathrm{BCC}$ of both PA and FL bacteria and temperature as well as $\mathrm{pH}$. Both environmental variables are related to phytoplankton dynamics. However, the BCC of PA Bacteria, but not of FL Bacteria or any actinobacterial fraction, correlated to PP. This notion indicates a close coupling mainly of PA Bacteria to phytoplankton development. In a former long-term study, we confirmed that temperature, $\mathrm{pH}$ and inorganic nutrients (phosphorus and nitrogen) were major drivers of $\mathrm{BCC}$ in mesotrophic Lake Tiefwaren (Rösel et al. 2012b). There, BCC also followed annually reoccurring seasonal patterns that were mainly forced by abiotic environmental conditions. During the present survey, temperature changes at the depth of sampling were rather low, and hence, we did not expect temperature to be a driving force for BCC succession. However, temporal changes in BCC were strongly correlated to temperature at the depth of sampling, suggesting that this correlation is mainly caused by time because temperature slightly but consistently increased throughout the sampling period. Hence, other time-dependent processes, such as succession of phytoplankton blooms and the availability of organic matter, seem to be of great importance for structuring natural freshwater BCC. 


\section{CONCLUSIONS}

It is well known that changes in abiotic and biotic variables act as important forces structuring bacterial communities in lakes. By frequent sampling in spring and early summer, we showed that the BCC of PA as well as FL Bacteria and Actinobacteria differ in dynamics during the temporal succession of phytoplankton, including the post-bloom phase in spring. Bacterial abundance and BPP were greatly enhanced after the phytoplankton spring bloom, indicating that bacterial colonisation and lysis of algal cells provide favourable conditions for pelagic bacteria, particularly of the PA fraction. Spatiotemporal changes in activity and BCC were closely related to changes in environmental conditions, e.g. phytoplankton development. Other environmental factors, such as temperature, $\mathrm{pH}$, availability of nutrients and organic matter, are also strongly but differently correlated with the BCC of either PA or FL Bacteria. Phylogenetic identifications of the organisms involved in these processes and measurements of the reoccurrence of specific functional phylogenetic groups of microorganisms will be helpful to untangle the relationship between $\mathrm{BCC}$ and specific environmental variables, in particular interactions of PA Bacteria with other micro- and macroorganisms.

Acknowledgements. The authors thank E. Mach and C. Wurzbacher for technical assistance and support during sampling. E. Mach is also thanked for measuring various limnological and biological parameters. This study was financially supported by the German Research Foundation (DFG GR1540/12-1) and the Leibniz Foundation.

\section{LITERATURE CITED}

Allgaier M, Grossart HP (2006) Seasonal dynamics and phylogenetic diversity of free-living and particle-associated bacterial communities in four lakes in northeastern Germany. Aquat Microb Ecol 45:115-128

> Allgaier M, Brückner S, Jasper E, Grossart HP (2007) Intraand inter-lake variability of free-living and particle-associated Actinobacteria communities. Environ Microbiol 9: 2728-2741

Allgaier M, Vogt M, Thyrhaug R, Riebesell U, Grossart HP (2008) Coupling of heterotrophic bacteria to phytoplankton bloom development at different $\mathrm{pCO}_{2}$ levels: a mesocosm study. Biogeosciences (Spec Issue) 5:317-359

Bell RT, Kuparinen J (1984) Assessing phytoplankton and bacterioplankton production during early spring in Lake Erken, Sweden. Appl Environ Microbiol 48:1221-1230

- Bunte C, Simon M (1999) Bacterioplankton turnover of dissolved free monosaccharides in a mesotrophic lake. Limnol Oceanogr 44:1862-1870

- Clarke KR (1993) Non-parametric multivariate analyses of changes in community structure. Austral Ecol 18:117-143
Clarke KR, Ainsworth M (1993) A method of linking multivariate community structure to environmental variables. Mar Ecol Prog Ser 92:205-219

> Cole JJ (1982) Interactions between bacteria and algae in aquatic ecosystems. Annu Rev Ecol Syst 13:291-314

Coveney MF, Wetzel RG (1995) Biomass, production, and specific growth rate of bacterioplankton and coupling to phytoplankton in an oligotrophic lake. Limnol Oceanogr 40:1187-1200

$>$ Doskey PV, Ugoagwu BJ (1989) Atmospheric deposition of macronutrients by pollen at a semi-remote site in northern Wisconsin. Atmos Environ 23:2761-2766

Eckert EM, Salcher MM, Posch T, Eugster B, Pernthaler J (2012) Rapid successions affect microbial $N$-acetyl-glucosamine uptake patterns during a lacustrine spring phytoplankton bloom. Environ Microbiol 14:794-806

Eiler A, Bertilsson S (2004) Composition of freshwater bacterial communities associated with cyanobacterial blooms in four Swedish lakes. Environ Microbiol 6:1228-1243

$>$ Eiler A, Olsson JA, Bertilsson S (2006) Diurnal variations in the auto- and heterotrophic activity of cyanobacterial phycospheres (Gloeotrichia echinulata) and the identity of attached bacteria. Freshw Biol 51:298-311

Glöckner FO, Zaichikov E, Belkova N, Denissova L, Pernthaler J, Pernthaler A, Amann R (2000) Comparative 16S rRNA analysis of lake bacterioplankton reveals globally distributed phylogenetic clusters including an abundant group of Actinobacteria. Appl Environ Microbiol 66: 5053-5065

Graham MD, Vinebrooke RD, Turner MD (2006) Coupling of boreal forests and lakes: effects of conifer pollen on littoral communities. Limnol Oceanogr 51:1524-1529

> Grossart HP (2010) Ecological consequences of bacterioplankton lifestyles: changes in concepts are needed. Environ Microbiol Rep 2:706-714

> Grossart HP, Tang KW (2010). www.aquaticmicrobial.net Commun Integr Biol 3:491-494.

> Grossart HP, Levold F, Allgaier M, Simon M, Brinkhoff T (2005) Marine diatom species harbour distinct bacterial communities. Environ Microbiol 7:860-873

> Grossart HP, Tang KW, Kiørboe T, Ploug H (2007) Comparison of cell-specific activity between free-living and attached bacteria using isolates and natural assemblages. FEMS Microbiol Lett 266:194-200

> Hill MO, Gauch HG (1980) Detrended correspondence analysis: an improved ordination technique. Plant Ecol 42:47-58

$>$ Jackson DA, Somers KM (1991) Putting things in order: the ups and downs of detrended correspondence analysis. Am Nat 137:704-712

Jones SE, Lennon JT (2010) Dormancy contributes to the maintenance of microbial diversity. Proc Natl Acad Sci USA 107:5881-5886

Kirchman D (2001) Measuring bacterial biomass production and growth rates from leucine incorporation in natural aquatic environments. In: John HP (ed) Methods in microbiology: Marine microbiology. Academic Press, New York, NY, p 227-237

> Lancelot C, Billen G (1984) Activity of heterotrophic bacteria and its coupling to primary production during the spring phytoplankton bloom in the southern bight of the North Sea. Limnol Oceanogr 29:721-730

> Lindström ES (2001) Investigating influential factors on bacterioplankton community composition: results from a field study of five mesotrophic lakes. Microb Ecol 42:598-605 
Mantel N (1967) The detection of disease clustering and a generalized regression approach. Cancer Res 27: 209-220

Muyzer G, Smalla K (1998) Application of denaturing gradient gel electrophoresis (DGGE) and temperature gradient gel electrophoresis (TGGE) in microbial ecology. Antonie van Leeuwenhoek 73:127-141

- Muyzer G, de Waal EC, Uitterlinden AG (1993) Profiling of complex microbial populations by denaturing gradient gel electrophoresis analysis of polymerase chain reaction-amplified genes coding for 16S rRNA. Appl Environ Microbiol 59:695-700

- Parveen B, Reveilliez JP, Mary I, Ravet V and others (2011) Diversity and dynamics of free-living and particle-associated Betaproteobacteria and Actinobacteria in relation to phytoplankton and zooplankton communities. FEMS Microbiol Ecol 77:461-476

> Peet RK, Knox RG, Case JS, Allen RB (1988) Putting things in order: the advantages of detrended correspondence analysis. Am Nat 131:924-934

Peng X, Fanxiang K, Huansheng C, Min Z (2007) Relationship between bacterioplankton and phytoplankton community dynamics during late spring and early summer in Lake Taihu, China. Acta Ecol Sin 27:1696-1702

> Pérez MT, Sommaruga R (2011) Temporal changes in the dominance of major planktonic bacterial groups in an alpine lake: discrepancy with their contribution to bacterial production. Aquat Microb Ecol 63:161-170

Porter KG, Feig YS (1980) The use of DAPI for identifying and counting aquatic microflora. Limnol Oceanogr 25: 943-948

Rink B, Grüner N, Brinkhoff T, Ziegelmüller K, Simon M (2011) Regional patterns of bacterial community composition and biogeochemical properties in the southern North Sea. Aquat Microb Ecol 63:207-222

Rösel S, Rychla A, Wurzbacher C, Grossart HP (2012a) Effects of pollen leaching and microbial degradation on organic carbon and nutrient availability in lake water. Aquat Sci 74:87-99

Rösel S, Allgaier M, Grossart HP (2012b) Long-term characterization of free-living and particle-associated bacterial communities in Lake Tiefwaren reveals distinct seasonal patterns. Microb Ecol doi:10.1007/s00248-012-0049-3

Salcher MM, Pernthaler J, Posch T (2010) Spatiotemporal distribution and activity patterns of bacteria from three phylogenetic groups in an oligomesotrophic lake. Limnol Oceanogr 55:846-856

Selje N, Simon M (2003) Composition and dynamics of particle-associated and free-living bacterial communities in the Weser estuary, Germany. Aquat Microb Ecol 30: 221-237

Editorial responsibility: Hugh Ducklow, Woods Hole, Massachusetts, USA
Šimek K, Nedoma J, Pernthaler J, Posch T, Dolan J (2002) Altering the balance between bacterial production and protistan bacterivory triggers shifts in freshwater bacterial community composition. Antonie van Leeuwenhoek 81:453-463

Šimek K, Horňák K, Jezbera J, Nedoma J, Znachor P, Hejzlar J, Sed'a J (2008) Spatio-temporal patterns of bacterioplankton production and community composition related to phytoplankton composition and protistan bacterivory in a dam reservoir. Aquat Microb Ecol 51: 249-262

Šimek K, Kasalický V, Zapomělová E, Horňák K (2011) Alga-derived substrates select for distinct betaproteobacterial lineages and contribute to niche separation in Limnohabitans strains. Appl Environ Microbiol 77: 7307-7315

- Simon M, Azam F (1989) Protein content and protein synthesis rates of planktonic marine bacteria. Mar Ecol Prog Ser 51:201-213

> Simon M, Tilzer MM (1987) Bacterial response to seasonal changes in primary production and phytoplankton biomass in Lake Constance. J Plankton Res 9:535-552

- Van den Wyngaert S, Salcher MM, Pernthaler J, Zeder M, Posch T (2011) Quantitative dominance of seasonally persistent filamentous cyanobacteria (Planktothrix rubescens) in the microbial assemblages of a temperate lake. Limnol Oceanogr 56:97-109

> Vrede K, Vrede T, Isaksson A, Karlsson A (1999) Effects of nutrients (phosphorous, nitrogen, and carbon) and zooplankton on bacterioplankton and phytoplankton-a seasonal study. Limnol Oceanogr 44:1616-1624

Weiss M, Simon M (1999) Consumption of labile dissolved organic matter by limnetic bacterioplankton: the relative significance of amino acids and carbohydrates. Aquat Microb Ecol 17:1-12

Weisse T, Müller H, Pinto-Coelho RM, Schweizer A, Springmann D, Baldringer G (1990) Response of the microbial loop to the phytoplankton spring bloom in a large prealpine lake. Limnol Oceanogr 35:781-794

Wetzel RG, Likens GE (1991) Limnological analysis, 2nd edn. Springer-Verlag, Heidelberg

Yannarell AC, Kent AD, Lauster GH, Kratz TK, Triplett EW (2003) Temporal patterns in bacterial communities in three temperate lakes of different trophic status. Microb Ecol 46:391-405

Yooseph S, Nealson KH, Rusch DB, McCrow JP and others (2010) Genomic and functional adaptation in surface ocean planktonic prokaryotes. Nature 468:60-66

Zwisler W, Selje N, Simon M (2003) Seasonal patterns of the bacterioplankton community composition in a large mesotrophic lake. Aquat Microb Ecol 31:211-225

Submitted: November 3, 2011; Accepted: April 2, 2012 Proofs received from author(s): May 9, 2012 